\title{
Depression, Anxiety and Stress among Dental Undergraduate Students: Prevalence, Stressors and Relieving Factors
}

\author{
Munirah Yaacob ${ }^{1}$, Nor Asilah Harun ${ }^{2}$, Farizah Ramli ${ }^{3}$, Hannah Abdul Razak ${ }^{4}$, Noor Aisyah Sajuni ${ }^{5}$, \\ ${ }^{1}$ Kulliyyah of Dentistry, International Islamic University Malaysia Kuantan \\ ${ }^{2}$ Faculty of Dentistry, UiTM Sungai Buloh Campus, Jalan Hospital, 47000 Sungai Buloh, Selangor Darul Ehsan \\ ${ }^{3}$ Klinik Pergigian Bandar Tun Razak, Bandar Tun Razak, 26900 Rompin, Pahang \\ ${ }^{4}$ Klinik Pergigian Bandar Jengka, Bandar Pusat jengka, 26400 Maran, Pahang \\ ${ }^{5}$ Klinik Pergigian Kota Tinggi, Jalan Tun Habab, 81900 Kota Tinggi, Johor
}

\begin{abstract}
Aim: To investigate the depression, anxiety and stress, stressors and relieving factors among dental students at Kulliyyah of Dentistry (KOD). Materials and methods: A cross-sectional study was conducted among 222 dental students. Their socio-demographic data, self-reported depression, anxiety and stress (DASS-21) scores, causes and relieving factors were collected using validated semi-structured pre-tested questionnaires. The data was analysed using percentages, chi-square test and Binary logistic regression tests with SPSS version 24 . Results: The prevalence of depression, anxiety and stress was $41 \%, 68.9 \%$ and $34.2 \%$ respectively. Cross analysis showed that academic-related and laboratory or clinical related reasons were significantly associated with the depressive symptoms $\left[\left(X^{2}=15.86, p<0.0001\right)\right.$ and $\left(X^{2}=10.45, p=0.001\right)$ respectively $]$ and stress symptoms $\left[\left(X^{2}=19.95, p<0.0001\right)\right.$ and $\left(X^{2}=6.11, p<0.05\right)$ respectively] among dental student. Furthermore, the item 'examination' being the highest factor chosen in academic-related stressors. The response for stress-relieving factors was high for Islamic ritual prayer/spiritual activities (94.6\%), sleeping $(86.5 \%)$ and doing exercise/playing sports $(76.1 \%)$, while 'seeking professional help' $(19.8 \%)$ was the least. Conclusion: This study shows that depressive, anxiety and stress symptoms are prevalent among dental students. Islamic ritual prayer and involvement in spiritual related activities was found to be the most preferred way for students to relief stress. Hence, it is vital that the university continually evaluates the psychological health of the students, tailor preventive measures and spiritual related programs to help students to cope with stress.
\end{abstract}

KEYWORDS: depression, anxiety, stress, dental students, Islamic ritual prayer

\section{INTRODUCTION}

Education is vital for any community ${ }^{1}$ and undoubtedly is a socioeconomic mobilization tool of the individuals in a nation. Thus, it is no surprise that an individual are willing to compete to achieve higher education level to improve their lives, becoming successful members of the community and active contributors to national development. ${ }^{2}$ The chase to achieve high academic levels can create a stressful environment during higher level of study. ${ }^{3}$ University students need to adjust themselves to various psychosocial changes in order to adapt themselves to academic and social demands in during their professional careers. ${ }^{4}$ If the students are not able to cope with the situation, and the stressful state is left untreated, it will lead to undesirably

Corresponding author:

Munirah binti Yaacob

Periodontics Unit,

Kulliyyah of Dentistry,

International Islamic University Malaysia,

Jalan Sultan Ahmad Shah, 25200 Kuantan,

Pahang, Malaysia.

Tel: +609 5705516, Fax: +609705580

Email: mun_ira@iium.edu.my levels of mental health, morbidity and that may have detrimental impact throughout their profession and life.

Depression, stress and anxiety levels are considered as important indicators for mental health in a community. In Malaysia, stress, anxiety and specifically depression affect approximately 2.3 million people ${ }^{5}$, with the prevalence of moderate to extremely severe level of depression, anxiety and stress among undergraduate students range from $13.9 \%$ to $29.3 \%, 51.5 \%$ to $55.0 \%$ and $12.9 \%$ to $21.6 \%$ respectively. ${ }^{6,7}$

A systematic review published in 2014 has reported that dental students too experience significant levels of stress. ${ }^{8}$ Dentistry has been shown as one of the more challenging, demanding and stressful field to study, as dental students are expected to obtain diverse competencies such as academic and clinical capabilities and social skills. ${ }^{9}$ In Malaysia, $100 \%$ of the University Malaya undergraduate dental students $^{10}$ and $89.7 \%$ of dentists ${ }^{11}$ were found to experience stressful situation. For them stress begins during dental school, and also varies in students in different years of study. ${ }^{12}$ 
IMJM Volume 17 Special Issue No 2

Studies had reported that the main stressors found among dental students were mainly both academicrelated $^{13}$ and personal-related factors. ${ }^{14}$ Stress due to academic-related factors was significantly associated with students in preclinical years, students while personal factors affected occur during clinical years. ${ }^{14}$ Academic and personalrelated factors were examination and grades, fear of failing during the course or lose a year, fear of being unable to catch up, inadequate time for relaxation, problem based learning sessions, completing the assignments, pressures of social issues with colleagues or patients, the stress of practice management, starting clinical practice and finally financial issues. ${ }^{10-15}$

Students practice many ways to cope with the stressful conditions. University of Malaya (UM) undergraduate students were chosen to be involved in spiritual activities, physical activity, seeking family support, and involving in dental faculty organization. ${ }^{10}$ Furthermore, a study found that UM students chose to talk to friends or go to sleep as coping methods. ${ }^{16}$

Undetected and untreated, mental health morbidity has been reported to be associated with many life threatening diseases such as death due to cardiovascular deaths, deaths from external causes or even cancer deaths, which was only associated with extreme mental health distress levels. ${ }^{17}$

Therefore, it is necessary to determine the level of mental health and stressors students' to enhance the quality of dental school learning environment. ${ }^{9}$ The aims of this study is to determine the depression, anxiety and stress level, the stressors, and the ideal solutions for among dental students at Kulliyyah of Dentistry (KOD), International Islamic University of Malaysia (IIUM).

\section{METHODS}

A cross-sectional study was conducted among undergraduate dental students of KOD. This research obtained approval from the Ethics and Research committee Kulliyyah of Medicine, IIUM. Students' volunteers from all the years of KOD were involved this study, with an exception for those on long medical leave and with known history of depression. This study was conducted between October 2013 and October 2014.

A pre-tested, self-administered questionnaire was used as the study instrument. A content expert in the field of counseling reviewed the questionnaires, which consists of four sections. The first section concentrates on the basic information on students, such as gender, current year of study, years spent in the course, marital status, parents' educational level and income status, and general personality type. The second section comprised of the shorter form of the Depression Anxiety Stress Scales (DASS21), which has been validated as screening tool by many researchers in a variety of socio-demographic conditions $^{18-20}$ and in Bahasa Malaysia (BM). ${ }^{21}$ Respondents were asked to rate 21 items based on how applicable the statements were to them over a past week. The total score were calculated based on the guideline in the manual. The third part of the questionnaire concentrates on the factors that lead to stress among students. Students are required to select and rate from the potential stressors, which are listed and comprised of factors related to academic, social, personal and clinical/laboratory environment. The potential stressors were then further sub-grouped and calculated as percentages of more than $50 \% \quad(>50 \%)$ and less than $50 \% \quad(\leq 50 \%)$ of the factor items selected.

The fourth section looked at the ways students were overcoming depression. This section lists several common activities that students can choose from. They are also required to rate their activities to see which is the most effective for them in relieving stress.

Following ethical approval of the study, students were contacted. The investigators were present while the students completed the questionnaires and signed the consent forms. Analysis of the data was done using percentages, chi-squares, and Binary logistic regression analysis.

\section{RESULTS}

Out of the 271 KOD students, 222 had volunteered and completed the questionnaires and hence used for final analysis. Table 1 shows the descriptive statistic of socio-demographic factors among respondents. The average age of respondents were 22 years old with a range from 20 to 23.8 years old. Majority of the respondents were female $(77.5 \%)$ with $99.5 \%$ were Malays. $14.4 \%$ of respondents were students who were repeating their studies. More than $50 \%$ of them were from clinical years.

Table 1. Socio-demographic of respondents $(\mathrm{N}=222)$

\begin{tabular}{|c|c|}
\hline Variables & $n(\%)$ \\
\hline Age (Mean \pm SD) & $22.19 \pm 1.80$ \\
\hline $\begin{array}{ll}\text { Gender } & \\
& \text { Male } \\
& \text { Female }\end{array}$ & $\begin{array}{c}50(22.5) \\
172(77.5)\end{array}$ \\
\hline $\begin{array}{ll}\text { Race } & \text { Malay } \\
& \text { Indian }\end{array}$ & $\begin{aligned} 221 & (99.5) \\
1 & (5)\end{aligned}$ \\
\hline $\begin{array}{l}\text { Marital status } \\
\text { Single } \\
\text { Married }\end{array}$ & $\begin{array}{c}217(97.8) \\
5(2.3)\end{array}$ \\
\hline $\begin{array}{r}\text { Personality } \\
\text { Extrovert } \\
\text { Introvert } \\
\text { Ambivert }\end{array}$ & $\begin{array}{l}43(19.4) \\
35(15.8) \\
144(64.9)\end{array}$ \\
\hline $\begin{array}{l}\text { Study status } \\
\text { Normal } \\
\text { Extended }\end{array}$ & $\begin{array}{l}190(85.6) \\
32(14.4)\end{array}$ \\
\hline $\begin{array}{l}\text { Study Years } \\
\text { Preclinical } \\
\text { Clinical }\end{array}$ & $\begin{array}{l}106(47.7) \\
116(52.3)\end{array}$ \\
\hline
\end{tabular}


Table 2 shows the prevalence of depression according to the severity (five-categories). According to depression group, $59 \%$ of the respondents were normal while $22.1 \%$, mild, $18 \%$, moderate and $2 \%$ of the respondents had severe depression respectively. Mean \pm Standard Deviation (SD) for depression score is $0.61 \pm 0.81$. For the anxiety status, $31.1 \%$ of the respondents were free from stress while the rest, ranging from $5.9 \%$ to $36.5 \%$. Mean \pm Standard Deviation for anxiety score is $1.49 \pm 1.22$. $65.8 \%$ of the respondents do not have any stress. The respondents having mild severity to extremely severe stress range from $21.6 \%$ to $5 \%$ with mean \pm SD is $0.49 \pm 1.78$.

Table 2 . Severity ratings $(n=222)$

\begin{tabular}{|c|c|c|c|}
\hline Severity & $\begin{array}{c}\text { Depression } \\
n(\%)\end{array}$ & $\begin{array}{c}\text { Anxiety } \\
n(\%)\end{array}$ & $\begin{array}{c}\text { Stress } \\
n(\%)\end{array}$ \\
\hline Normal & $131(59)$ & $\begin{array}{c}69 \\
(31.1)\end{array}$ & $146(65.8)$ \\
\hline Mild & $49(22.1)$ & $\begin{array}{c}30 \\
(13.5)\end{array}$ & $48(21.6)$ \\
\hline Moderate & $40(18)$ & $\begin{array}{c}81 \\
(36.5)\end{array}$ & $24(10.8)$ \\
\hline Severe & $2(9)$ & 29 & $3(1.4)$ \\
\hline Extremely severe & 0 & $13(5.9)$ & $1(5)$ \\
\hline Mean \pm SD & $0.61 \pm 0.81$ & $\begin{array}{r}1.49 \\
\pm 1.22\end{array}$ & $0.49 \pm 1.78$ \\
\hline
\end{tabular}

Table 3 shows that only academic-related $\left(X^{2}=\right.$ 15.86, $\mathrm{p}<0.0001)$ and clinical/laboratory related $\left(X^{2}=10.45, \quad p=0.001\right)$ causes significantly differ between depressive and non-depressive group. Similar results were found for stress domain, academic-related $\left(X^{2}=19.95, \quad \mathrm{p}<0.0001\right)$ and clinical/laboratory related $\left(X^{2}=6.11, p<0.05\right)$ causes show significant different between stress and nonstress group. In addition, male students showed significantly higher stress level compared to females $\left(X^{2}=3.97, p=0.05\right)$. For anxiety group, only personalrelated stressors showed significant difference $\left(X^{2}=6.50, p<0.05\right)$.

After further regression analysis using Binary logistic regression was conducted (in Table 4), no significant difference was found in all variables examined with depression, anxiety and stress domain. Though the academic-related causes $(>50 \%)$ show point significant relationship with stress domain $(p<0.05)$, it is questionable because the upper limit of $95 \% \mathrm{Cl}$ is 1 [Unadjusted OR $(95 \% \mathrm{Cl})=0.4(0.2-1.0)$ ]. No association was found for socio-demographic variables and other sources of stress with depression and anxiety domain.

Table 3. Bivariate analysis of the association of the socio-demographic factors and sources of stress with depression, anxiety and stress.

\begin{tabular}{|c|c|c|c|c|c|c|}
\hline \multirow[t]{2}{*}{ Variables } & \multicolumn{2}{|c|}{$\begin{array}{c}\text { Depression }(\mathrm{n}=222) \\
n(\%)\end{array}$} & \multicolumn{2}{|c|}{$\begin{array}{c}\text { Anxiety }(\mathrm{n}=222) \\
n(\%)\end{array}$} & \multicolumn{2}{|c|}{$\begin{array}{c}\text { Stress }(\mathrm{n}=222) \\
n(\%)\end{array}$} \\
\hline & + & - & + & - & + & - \\
\hline \multicolumn{7}{|l|}{ Gender } \\
\hline Male & $23(46)$ & $27(54)$ & $39(78)$ & $11(22)$ & $23(46)$ & 27 (54) \\
\hline \multirow[t]{2}{*}{ Female } & $68(40)$ & $104(61)$ & $114(66)$ & $5(34)$ & $53(31)$ & 119 (69) \\
\hline & \multicolumn{2}{|c|}{$\begin{aligned} X^{2} & =0.669 \\
p & >0.05\end{aligned}$} & \multicolumn{2}{|c|}{$\begin{array}{c}X^{2}=2.48 \\
p>0.05\end{array}$} & \multicolumn{2}{|c|}{$\begin{array}{l}X^{2}=3.97 \\
p=0.05\end{array}$} \\
\hline \multicolumn{7}{|l|}{ Marital status } \\
\hline Single & $90(41.5)$ & 127 (59) & 150 (69) & $67(31)$ & 74 (34) & $143(66)$ \\
\hline \multirow[t]{2}{*}{ Married } & $1(20)$ & $4(80)$ & $3(60)$ & $2(40)$ & $2(40)$ & $3(60)$ \\
\hline & \multicolumn{2}{|c|}{$\begin{array}{c}X^{2}=0.932 \\
{ }^{*} p>0.05\end{array}$} & \multicolumn{2}{|c|}{$\begin{aligned} X^{2} & =0.190 \\
& * p>0.05\end{aligned}$} & \multicolumn{2}{|c|}{$\begin{aligned} x^{2} & =0.076 \\
p & >0.05\end{aligned}$} \\
\hline \multicolumn{7}{|l|}{ Study status } \\
\hline Normal & 81 (43) & 109 (57) & 132 (70) & $58(31)$ & $65(34)$ & $125(66)$ \\
\hline \multirow[t]{2}{*}{ Extended } & $10(31)$ & 22 (69) & $21(66)$ & 11 (34) & 11 (34) & $21(66)$ \\
\hline & \multicolumn{2}{|c|}{$\begin{array}{l}X^{2}=1.47 \\
p>0.05\end{array}$} & \multicolumn{2}{|c|}{$\begin{array}{l}X^{2}=0.189 \\
p>0.05\end{array}$} & \multicolumn{2}{|c|}{$\begin{aligned} X^{2} & =0.000 \\
p & >0.05\end{aligned}$} \\
\hline \multirow{4}{*}{$\begin{array}{l}\text { Study year } \\
\text { Preclinical } \\
\text { Clinical }\end{array}$} & & & & & & \\
\hline & $45(41)$ & 61 (47) & 79 (76) & $27(26)$ & $36(34)$ & $70(66)$ \\
\hline & $46(40)$ & $70(60)$ & 74 (64) & 42 (36) & $40(35)$ & $76(66)$ \\
\hline & \multicolumn{2}{|c|}{$\begin{aligned} X^{2} & =0.179 \\
p & >0.05\end{aligned}$} & \multicolumn{2}{|c|}{$\begin{aligned} X^{2} & =2.98 \\
p & >0.05\end{aligned}$} & \multicolumn{2}{|c|}{$\begin{aligned} X^{2} & =0.007 \\
p & >0.05\end{aligned}$} \\
\hline \multicolumn{7}{|l|}{ Personality } \\
\hline Extrovert & $22(51)$ & $21(49)$ & $31(71)$ & $12(28)$ & $18(42)$ & $25(58)$ \\
\hline Introvert & $13(37)$ & 22 (63) & 27 (77) & $8(23)$ & 13 (37) & 22 (63) \\
\hline Ambivert & 56 (39) & 88 (61) & $95(66)$ & $49(34)$ & $45(31)$ & 99 (69) \\
\hline & \multicolumn{2}{|c|}{$\begin{array}{l}X^{2}=2.32 \\
p>0.05\end{array}$} & \multicolumn{2}{|c|}{$\begin{aligned} X^{2} & =0.000 \\
p & >0.05\end{aligned}$} & \multicolumn{2}{|c|}{$\begin{array}{l}X^{2}=1.81 \\
p>0.05\end{array}$} \\
\hline
\end{tabular}




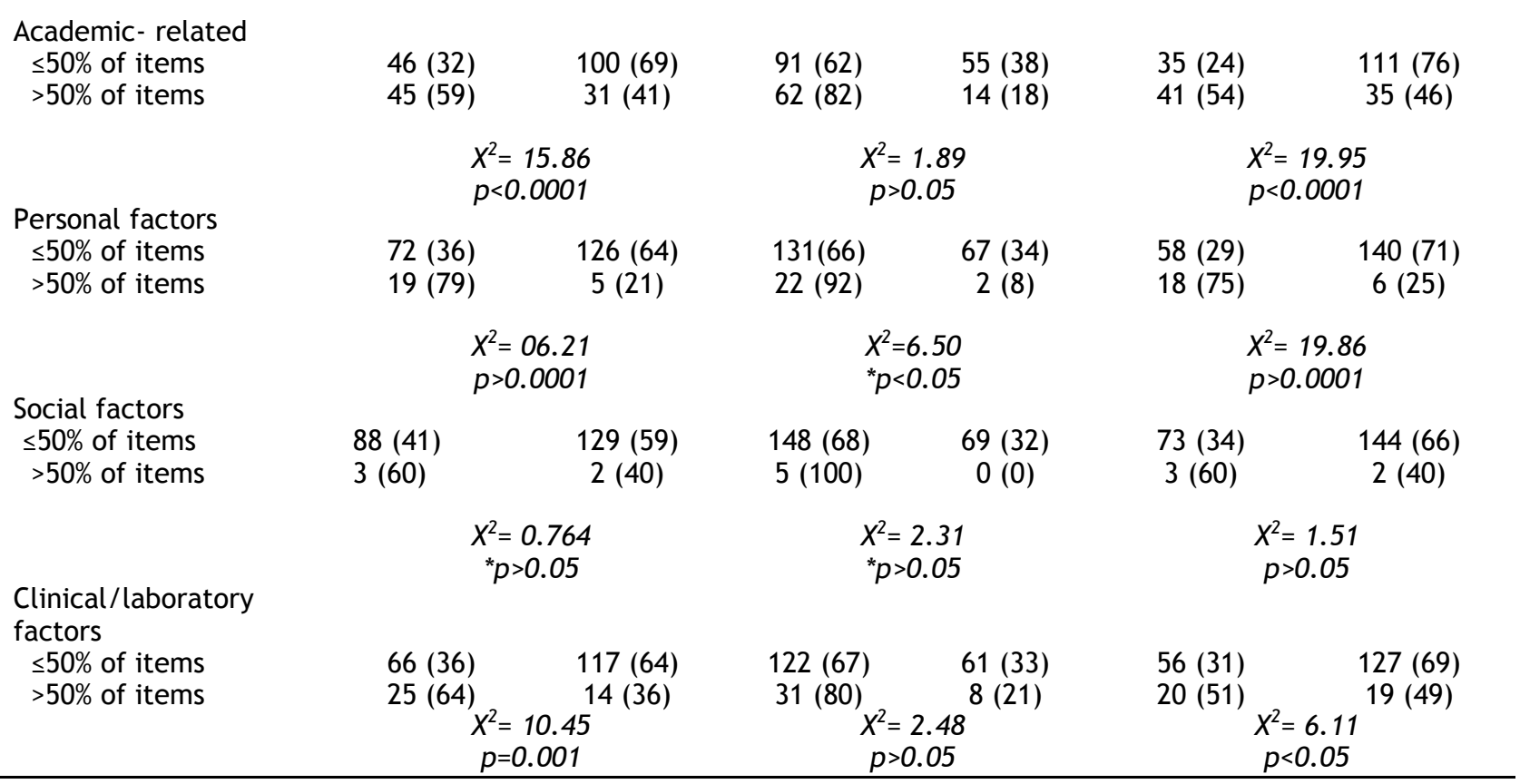

$X^{2}$; Chi-square test, *Fisher's exact test

Table 4. Binary logistic regression of socio-demographic factors and causes of stress association with depression, anxiety and stress group

\begin{tabular}{|c|c|c|c|}
\hline Variables & $\begin{array}{c}\text { Depression }(n=91) \\
\text { Unadjusted OR } \\
(95 \% \mathrm{Cl})\end{array}$ & $\begin{array}{c}\text { Anxiety }(n=153) \\
\text { Unadjusted OR } \\
(95 \% \mathrm{Cl})\end{array}$ & $\begin{array}{c}\text { Stress }(n=76) \\
\text { Unadjusted OR } \\
(95 \% \mathrm{Cl})\end{array}$ \\
\hline Gender & $1.1(0.5-2.3)$ & $1.2(0.5-2.8)$ & $1.6(0.7-3.5)$ \\
\hline Marital status & $2.9(0.2-37.8)$ & $1.9(0.2-19.3)$ & $0.5(0.1-4.9)$ \\
\hline Study status & $1.7(0.6-4.8)$ & $0.6(0.2-1.7)$ & $0.8(0.2-2.3)$ \\
\hline Study years & $1.3(0.6-2.6)$ & $2.6(1.2-5.7)$ & $1.3(0.7-2.9)$ \\
\hline $\begin{array}{l}\text { Personality: } \\
\text { Extrovert }\end{array}$ & $1.4(0.6-3.1)$ & $0.8(0.3-2.0)$ & $1.2(0.5-2.9)$ \\
\hline $\begin{array}{l}\text { Stressors: Academic factors } \\
>50 \% \text { of items }\end{array}$ & $0.6(0.3-1.3)$ & $0.6(0.2-1.4)$ & $0.4(0.2-1.0)^{*}$ \\
\hline $\begin{array}{l}\text { Stressors: personal factors } \\
>50 \% \text { of items }\end{array}$ & $0.4(0.1-1.4)$ & $0.9(0.1-5.2)$ & $0.3(0.1-1.1)$ \\
\hline $\begin{array}{l}\text { Stressors: Social factors } \\
>50 \% \text { of items }\end{array}$ & $2.2(0.3-19.5)$ & 0.00 & $1.1(0.1-8.7)$ \\
\hline $\begin{array}{l}\text { Stressors: Clinical/laboratory } \\
>50 \% \text { of items }\end{array}$ & $0.4(0.2-1.2)$ & $1.1(0.3-2.4)$ & $1.4(0.4-4.4)$ \\
\hline
\end{tabular}

${ }^{*} p<0.05$

Table 5. Factor relieving stress

\begin{tabular}{lc}
\hline \multicolumn{1}{c}{ Relieving factors } & $n(\%)$ \\
\hline Reduction of contact hours & $61(27.5)$ \\
Reduction of study requirements & $119(53.6)$ \\
Provide a slot for laboratory work & $162(73)$ \\
Buddy (mentor-mentee) system between students & $72(32.4)$ \\
Mentor-mentee system between students and lecturers & $82(36.9)$ \\
Praying/ doing any spiritual activities & $210(94.6)$ \\
Talking to parents/ family members & $164(73.9)$ \\
Sleeping & $192(86.5)$ \\
Joining extra-curricular activities & $119(53.6)$ \\
Seeking professional help (counselors, doctors, etc.) & $44(19.8)$ \\
Watching/ listening to motivational talks & $100(45)$ \\
Doing exercise/ playing sports & $169(76.1)$ \\
Others & $9(4.1)$ \\
\hline
\end{tabular}




\section{DISCUSSION}

Among the 222 dental students, the prevalence of depression, anxiety and in the study stress symptoms were $41 \%, 68.9 \%$ and $34.2 \%$ respectively. This prevalence was higher compared to a study using similar instruments among the university students elsewhere in Malaysia ${ }^{3}$ that stated that the prevalence of depression, anxiety and stress of moderate and above severity were $37.2 \%, 63.0 \%$ and $23.7 \%$, respectively. Prevalence from other studies was ranged from $13.9 \%$ to $29.3 \%, 51.5 \%$ to $55.0 \%$ and $12.9 \%$ to $21.6 \%$ for mild to severe category respectively. ${ }^{6,7}$ The prevalence was high because in addition to coping with the normal stressors of everyday life, dental students have to deal with stressors specific to study in the dental school, which includes learning clinical procedure, completion of specified number of patients coupled, gaining competency in academic. ${ }^{22-23}$

In this cross-sectional study we correlated certain risk factors such as gender, study year, study status, personality trait of the student and the identified causes for stress with the prevalence of depression, anxiety and stress amongst the dental students of KOD. From cross-analysis, our study revealed that academic-related causes were significantly associated with two domains; the depressive and stress symptoms in dental students. Similar results were reported by other studies., ${ }^{8,10,13,27}$ However, analysis using binary logistic regression refutes this association. In addition, many studies showed that dental students feel academic pressure due to frequent academic examinations in a competitive environment. ${ }^{10,13}$ Similar findings have been observed in this study. "Examination" (mean \pm SD; $2.05 \pm 0.85$ ) was chosen as the most stressful event for dental students followed by "load of assignments given", "difficulty in understanding the lectures" and "fear of being unable to catch up with studies". Additionally the analysis shows that the clinical or laboratory issues stated below were found significantly associated with depressive and stress symptoms. During the clinical session, students are expected to be ready to manage any type of patient'. Self-unpreparedness and high expectation from clinical lecturer may create a stressful condition for students during clinical sessions. Moreover, there is no time allocated in the timetable for laboratory work. Students are required to find their own time to spend in the laboratory, which may be after office hours and during weekend. Therefore, those who have poor management of time will feel that the 'extra' laboratory work as a burden and a source of stress for them.

Some research has linked stress symptoms with gender, academic year and living environment. Although in this study male students were found to show significant difference in stress coping compared to female students, further regression analysis had reverted this association. Between genders studies in Malaysia report that female students had higher stress level compared to male ${ }^{6,13,27}$, whereas some studies found no differences. Piccinelli and Wilkinson ${ }^{28}$, stated although there are perspectives that females are more prone to depression, gender differences are far from being established and their association to the etio-pathogenic models are lacking. Stress levels were observed varied significantly across the year of studies. ${ }^{6,13,27}$ Telang et al. ${ }^{27}$, reported that the transitional years from preclinical (year 2) to the clinical years (year 3 ) to be the most stressful time for dental undergraduates as they have to see patients and to meet new clinical requirements.

Interestingly, our study found that the most frequently reported 'other causes' of stress for dental students was weight gain. The finding corresponds with the 'other' most commonly reported stress relieving by eating. Some students seem to eat more when they were stress and eventually gaining weight that make them even stressed. Several students also reported that students' habit of procrastination, having stern lecturers and staffs, and strict clinic regulations are noteworthy causes of depression, anxiety and stress. Thus, it is imperative for students themselves to develop regular study habits, and avoid last-minute completion of work. Apart from that, perhaps a time-management course may be included in the curriculum. ${ }^{29}$ Lecturers should also be aware that undue expectations in academic achievement could lead to stress.

A total of $94.6 \%$ of respondents reported that praying or doing any spiritual activities as a significant reliever of depression, anxiety and stress as it provides calmness and hope for a better life. ${ }^{30}$ This is in-line with the study by Ahmad et al. ${ }^{10}$. The use of spirituality and religious practice, according to Rosmarin et al. ${ }^{31}$, in the form of adaptive manner can be helpful to individual who have series of psychological distress. This was also reported by Krauss et al. ${ }^{32}$ Watterson and Giesler ${ }^{33}$ stated that religious people posed higher level self-control thus they are more able to persist in difficult tasks and life situation. Furthermore, a total of $76.1 \%$ of students reported that exercising or playing sports as being helpful. Therefore, the provision of spiritual programs and sports activities at the university for the undergraduate students on a frequent basis is essential.

In Islamic teaching, many solutions can be practiced from spiritual perspective to overcome depression, anxiety or stress. ${ }^{34-36}$ According to attachment theory by John Bowlby ${ }^{37}$, in the "Maternal care and mental health", "having a secure attachment has been linked to the over-all wellbeing, coping, better mental health outcomes, enhanced self-esteem, and stronger relationship functioning". Thus, having a "healthy attachment" to God would also be linked to better psychological functioning. Al-Quran had related this in chapter 65 verses No. 3 "...Whosoever puts his trust in Allah, then He will suffice 
him..." [Quran, 65:3].

Imam Nawawi has narrated in Riyadus Saliheen that an individual who put 'tawakkul' (means trust on god) in Allah after has working hard in achieving their goals; Allah will protect them from anxiety and worries. Ibn 'Abbas reported that the Messenger of Allah, (may Allah bless him and grant him peace), used to say, "O Allah, I submit to you and I believe in you and I have relied on you and I turn to you and I have argued by you. I seek refuge with Your mighty, there is no god other than You, from Your misguiding me. You are the Living who does not die while jinn and men will all die." ${ }^{38}$

The simplest ways to overcoming any difficulties in worldly life is by means of 'dua' (supplication) to seek god guidance and protection. Al-Quran has address in chapter 7 verses no 55 to 56 the significance of 'dua'; "Call on your Lord with humility and in private: for Allah loved not those who trespass beyond bounds. Do not make mischief on the earth, after it hath been set in order, but call on Him with fear. And longing (in your hearts): for the mercy of Allah is (always) near to those who do good".$^{39}$ Other spiritual coping strategy that has been proposed includes reciting Al-Quran, fasting, mid-day nap, meditation, music therapy and giving charity. ${ }^{40,41}$ The above deeds are mainly aimed for purification of heart and eventually have an easing effect on stress, anxiety or depression in an individual.

There are several limitations to this study. This research is limited to the volunteers in IIUM, specifically KOD. In addition, this study is based on results from a self-administered questionnaire; therefore some reporting bias is a possibility. Also, this study does not take into consideration the difference in depression, anxiety and stress levels at different times, such as during pre-examination and post-examination periods. Future study should also include the consequences of these mental health morbidities to dental students.

In conclusion, the depressive, anxiety and stress symptoms is prevalent among dental students. It is important to understand the differences between these three to allow for effective screening and monitoring of the vulnerable students at the earliest possible stage. This is to provide intervention, support and necessary treatment as anxiety left untreated may progress to stress and subsequently, depression. Moreover, the university may want to consider, regular provision of more Islamic or spiritual related activities that is tailored to help students to overcome their anxiety, stress and depression.

\section{ACKNOWLEDGEMENT}

We would like to thank Asst Prof Dr Tin Myo Han, Mdm Rina Suryani Binti Arif, Associate Prof Dr Norlide bte Abu Kassim and all the students from Kulliyyah of Dentistry, IIUM for their contribution in this study. This publication is supported by IIUM
RIGS 16-330-0494.

\section{REFERENCES}

1. Wan Daud WMN Falsafah dan amalan pendidikan islam Syed M Naquib Al-Attas: Satu. Huraian konsep asli islamisasi. Kuala Lumpur: Universiti Malaya, 2005.

2. Ministry of Education. 2012. Malaysia Education Blueprint 2013-2025 [online]. Available at: https://www.moe.gov.my/images/dasar-kpm/ articlefile_file_003108.pdf

3. Shamsuddin K, Fadzil F, Ismail A, et al. Correlates of depression, anxiety, and stress among Malaysian university students. Asian J Psychiatr 2013; 6(4):318-323.

4. Uehera E, Flynn M, Fong R, et al. JSSWR 2013; 4 (3):165-170.

5. Mukhtar F, Tian, PO A review on the prevalence of depression in Malaysia. Curr Psychiatry Rev 2011; 7(3):234-238.

6. Gan WY, Mohd Nasir MT, Shariff ZM, et al. Disordered eating behaviours, depression, anxiety and stress among Malaysian university students. Coll Stud J 2011; 45:296.

7. Al-Ani Radeef AS, Ghazi FG Depression, Anxiety and Stress among Undergraduate Science Students in Malaysia. 17th Johor Mental Health Conference, Malaysia, 2015.

8. Elani HW, Allison PJ, Kumar RA, et al. A systematic review of stress in dental students. JDent Educ 2014; 78:226-242.

9. Divaris K, Polychronopoulou A. Dental students' perceived sources of stress: a multi-country study. J Dent Educ 2009; 3(5):631-9.

10. Ahmad MS, Ishak AR, Mohd MMY Stress and its relief among undergraduate dental students in Malaysia. Southeast Asian J Trop Med Public Health. 2011; 42(4):996-1004.

11. Khalid K Work-related stress among government dentists and dental nurse. Dissertation. Kuala Lumpur: University of Malaya, 2000.

12. Peker I, Alkurt MT, Usta MG, et al. The evaluation of perceived sources of stress and stress levels among Turkish dental students. Int Dent J 2009; 59: 103-11.

13. Muneer GB, Syed SH, Yong JO, et al. Perceived sources of stress among Malaysian dental students. Int J Med Educ 2015; 6:56-61.

14. Naidu RS, Adams JS, Simeon D, et al. Sources of stress and psychological disturbance among dental students in the West Indies. J Dent Educ 2002; 66(9): 1021-30.

15. Rada RE, Johnson LC Stress, burnout, anxiety and depression among dentists. J Am Dent Assoc 2004; 135(6):788-94.

16. Shah C, Trivedi RS, Diwan J, et al. Common stressors and coping of stress. Medical Students. J ClinDiagn Res 2009; 3:1621-1626.

17. Russ TC, Stamatakis E, Hamer M, et al. Association between psycho- logical distress and mortality: individual participant pooled analysis of 10 prospective cohort studies. BMJ 2013; 345:e4933. 
18. Xavier S, Bento E, Azevedo J, et al. Validation of the Depression, Anxiety and Stress ScaleDASS-21 in a community sample of Portuguese pregnant women. Eur Psychiatry 2016; 3 (s):S239.

19. Osman $A$, Wong JL, Bagge $C L$, et al. The Depression Anxiety Stress Scales-21 (DASS-21): further examination of dimensions, scale reliability, and correlates. J Soc Clin Psychol 2012; 68(12):1322-38.

20. Tian PO, Sukanlaya SS, Yong WG, et al. Using the Depression Anxiety Stress Scale 21 (DASS21) across cultures. Int J Psychol 2013; 48(6):1018-1029.

21. Ramli M, Rosnani S, Aidil Faszrul, AR Psychometric Profile of Malaysian version of the Depressive, Anxiety and Stress Scale 42-item (DASS-42). MJP 2012; 21(1).

22. Sekhon TS, Grewal S, Gambhir RS,et al.. Perceived sources of stress among dental college students: An Indian perspective. Adv Med Educ Prac 2015. 4(3):121-126.

23. Al-Saleh SA, Al-Madi EM, Al-Angari NS, et al. Survey of perceived stress-inducing problems among dental students, Saudi Arabia. Saudi Dent J 2010; 22:83-8.

24. Heath JR, MacFarlane TV, Umar MS. Perceived sources of stress in dental students. Dent Update 1999; 26(3):94-98.

25. Sanders AE, Lushington $K$ Sources of stress for Australian dental students. J Dent Educ 1999; 63(9):688-697.

26. Alzahem AM, Van der Molen HT, De Boer BJ. Effect of year on study on stress levels in male undergraduate dental students. Adv Med Educ Prac 2013; 4:217 -222.

27. Telang HA, Nerali JT, Telang A, et al. Perceived sources of stress among Malaysian dental students. European J Gen Dent 2013; 2(30):300307.

28. Piccinelli $M$, Wilkinson $G$ Gender differences in depression. Critical Review. Br J Psychiatry. 2000; 177:486-92.

29. Waghachavare VB., Dhumala GB, Kadam YR, et al. A study of stress among students of professional colleges from an urban area in India. Sultan Qaboos Univ Med J 2013; 13(3):429-436.

30. Bormann JE, Smith TL, Becker S, et al. Efficacy of frequent mantram repetition on stress, quality of life, and spiritual well-being in veterans: A pilot study. J Holist Nurs 2005; 23(4):394-413.

31. Rosmarin DH, Pargament KI, Pirutiasky S, et al. A randomized controlled evaluation of a spiritually integrated treatment for subclinical anxiety in the Jewish community, delivered via the Internet. J Anxiety Disord 2010; 24:799-

808.

32. Krauss SE Development of the muslim religiosity- personality inventory for measuring the religiousity of Malaysia muslim youth. Unpublished Ph.D. Thesis. Universiti Putra Malaysia: Serdang, 2005.

33. Watterson K, Giesler B Religiosity and self- control: when the going gets tough, the religious get self-regulated. Psychology of Religion and Spirituality 2012; 4(3):193-205.

34. Beekun R Follow Muhammad's (s) Sunnah: Take a power nap to increase alertness and productivity [online]. Available at: http://theislamicworkplace.com/2011/05/01/f ollow -muhammads-s- sunnah-take-a-powernap-to-increase-alertness-and-productivity/ Accessed September 15, 2016.

35. Casey K Should employees be allowed to nap at work? [online]. Available at https://www. mint.com/blog/trends / nappingat-work-12212010/ Accessed September 15, 2016.

36. Sarhandi KA Urdu Tarjamah-Yi. Kitab Maktubat Sharif. Vol. 143: Allah vale ki qaumi dukan, 1976.

37. Bowlby J Maternal care and mental health. Geneva: Monograph World Health Organization, 1952.

38. Saliheen R Imam Abu Zakaria Mohiuddin Yahya An-Nawawi (RA): Translation by Ustadha Aisha Bewley [online]. http://ahadith.co.uk/downloads/riyadus_saleh een.pdf (Accessed October 4, 2016).

39. AL-Quran, Chapter 7, Verses 55-56.

40. Hassan MS, Mir RU, Hassan SS. Spirituality and workplace stress management. Al-Adwa 2015; 44:30.

41. Sabry WM, Vohra A Role of Islam in the management of Psychiatric disorders. Indian J Psychiatry 2013. 55(Suppl 2):S205-S214. 
